\title{
DESIGN AND ANALYSIS OF MANGANESE ALLOY STEEL CONNECTING ROD
}

\author{
M.Hariharan, V.Kalaigowtham, S.Aravind \\ Bachelor of Engineering \\ Department of Mechanical Engineering
}

Dhirajlal Gandhi College of Technology, Salem.

Dr.P.Parandaman

Associate Professor,

Department of Mechanical Engineering

Dhirajlal Gandhi College of Technology, Salem.

\author{
Dr.A.Selvaraj \\ Professor and Head, \\ Department of Mechanical Engineering \\ Dhirajlal Gandhi College of Technology, Salem.
}

\begin{abstract}
A connecting rod is an intermediate element between the piston and the Crankshaft in an IC engine. Its primary function is to transmit the push and pull from the piston to the crank shaft by converting the reciprocating motion of the piston into rotary motion of the crank shaft. A connecting rod is subjected to various forces. Also connecting rod is a critical element in an IC engine because it is easily damageable. Hence designing a connecting rod is very important. Now-a-days connecting rods used in automotive industries are made up of structural steel, titanium, forged steel and cast iron. Currently existing connecting rod is manufactured by using forged steel. The purpose of this work is to replacement of forged steel by Manganese alloy steel to obtain the best performance. Manganese alloy steel has better physical and mechanical properties like high hardness, strength, abrasion resistance and hardenability. Connecting rod made up of manganese alloy steel gives high performance at low cost. In this work the connecting rod made up of manganese alloy steel is designed in CATIA V15 and the static analysis is done in ANSYS V14.2 software.
\end{abstract}

Keywords - Connecting rod, 4-Stroke IC Engine, Designed manganese alloy steel connecting rod, Analysis of connecting rod, CATIA V15 and ANSYS V14.2 software.

\section{INTRODUCTION}

In a reciprocating $\mathrm{IC}$ engine the connecting rod connects piston to the crankshaft. Concern with the parts, they form a simple mechanism that converts reciprocating motion into rotary motion. Connecting rod transmits push and pull forces from the piston pin to the crank pin. Main parts of connecting rod shown in fig.1

It also transfers the lubrication oil from the crank end to the piston pin and provides a splash or jet of oil to the piston assembly. They are different types of materials and production methods used in the creation of connecting rods. Chen et al. (2006) States that the major stresses induced in the connecting rod are combination of axial and bending stresses in operation [1-4]. The axial stresses are produced due to cylinder gas pressure (compressive only) and the inertia force arising in account of reciprocating action (both tensile as well as compressive) whereas bending stresses are caused due to the centrifugal effects. It consists of an eye at the small end to accommodate the piston pin, a long shank and a big end. Afzal (2004) studied the Connecting rod is subjected to a complex state of loading. It undergoes high cyclic loads of the order of $10^{\wedge} 8$ to $10^{\wedge} 9$ cycles, which range from high compressive loads due to combustion to high tensile loads due to inertia[5].

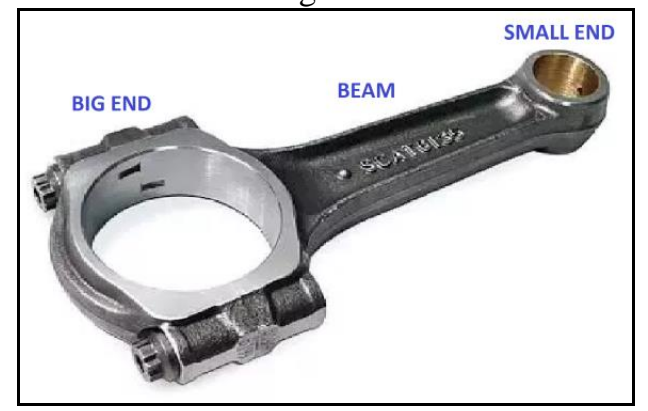

Fig. 1. Connecting rod 


\section{International Journal of Engineering Applied Sciences and Technology, 2020 \\ Vol. 4, Issue 12, ISSN No. 2455-2143, Pages 562-569 \\ Published Online April 2020 in IJEAST (http://www.ijeast.com)}

\section{A. Function of Connecting Rod in an IC Engine:}

The main function of connecting rod is to transmit the thrust of the piston to the crankshaft. The purpose of connecting rod from reciprocating motion into rotary motion. The four strokes of internal combustion engine are intake, compression, expansion or power and exhaust.

Every stroke requires around 180 degrees of crankshaft rotation, so the complete cycle would take 720 degrees. Every stroke of the engine plays a very important role in the combustion process.

Initially, the inlet valve opens and the piston moves downward, one of the valve open. This creates a vacuum and an air-fuel mixture is admitting into the chamber. On the second stroke compression occurs. In compression both the valve are closed, the piston moves upward and thus creates a pressure on the piston. The next stroke is the power. In this process the compressed air-fuel mixture is ignited with a spark because of this a tremendous pressure as the fuel burns.

The forces exerted by piston transferred through the connecting rod moves the crankshaft. Finally the exhaust stroke occurs. In this stroke, the exhaust valve opens; as the piston moves inwards to release the combustion products from the cylinder at constant pressure. It forces all the air out of the chamber and thus which completes the cycle of crankshaft rotation.

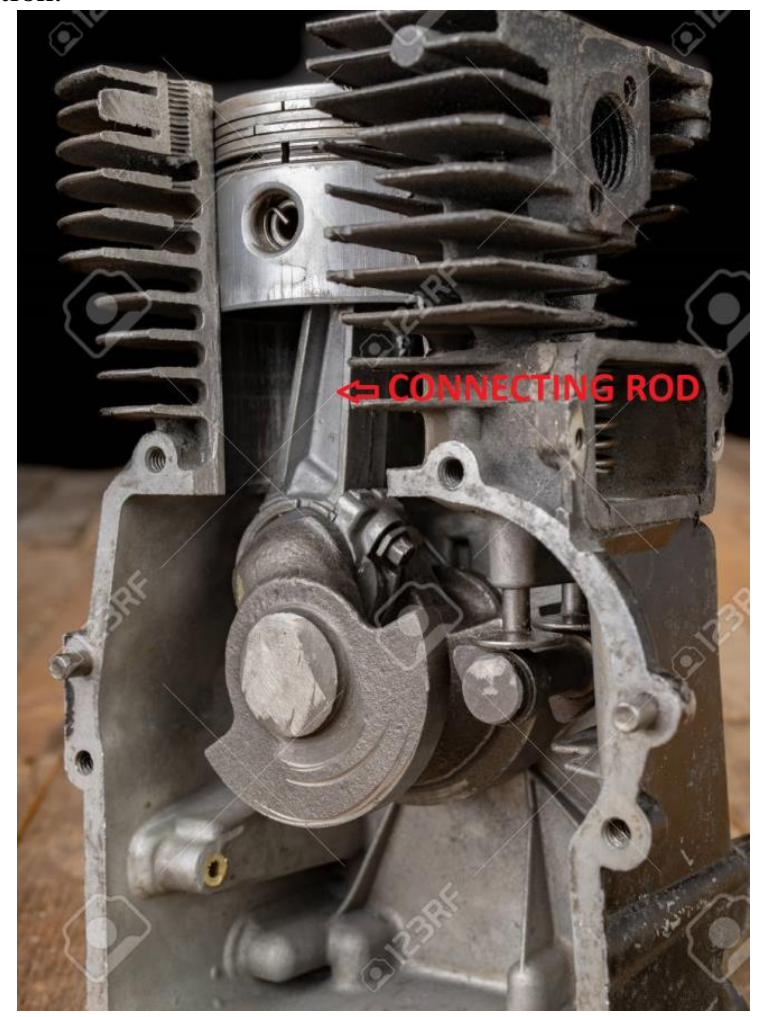

Fig. 2. Connecting rod in IC Engine

\section{SPECIFICATION OF IC ENGINE}

We are taking $150 \mathrm{cc}$ Suzuki gixxer bike engine specifications. The Suzuki gixxer is a 154.9 cc (9.45) naked motorcycle from Suzuki. The bike was launched in September 2014. This design is similar to the GSX-S100. This is a standard class. This engine is air cooled and SHOE engine. This is 5-speed constant mesh transmission type motorcycle. it is diamond frame type bike. Front suspension is telescope and rear suspension is swing arm, 7 step adjustable mono suspension. The wheelbase is 1330 millimeter. The length of the vehicle is 2050 millimeter. The width of the vehicle is 785 millimeter. The height of the vehicle is 1030 millimeter. The fuel capacity is 12 litters.

\section{A. Engine Parameters:}

Engine type air cooled 4-stroke

Bore x Stroke (mm)

Displacement

Maximum Power

Maximum Torque

Compression Ratio

Density of Petrol C8H18

Temperature

$$
\begin{aligned}
& =57 \times 58.6 \\
& =149.5 \mathrm{CC} \\
& =13.8 \mathrm{bhp} @ 8500 \mathrm{rpm} \\
& =13.4 \mathrm{Nm} @ 6000 \mathrm{rpm} \\
& =9.35 / 1 \\
& =737.22 \mathrm{~kg} / \mathrm{m}^{3} \\
& =737.22 \mathrm{E}-9 \mathrm{~kg} / \mathrm{mm}^{3} \\
& =60^{\circ} \mathrm{F}
\end{aligned}
$$

Where,

We need the temperature in Kelvin, so the ${ }^{\circ} \mathrm{F}$ converting into Kelvin. Formula is,

$($ Degree Fahrenheit -32$) \times 5 / 9+273.15=289$ Kelvin

Temperature $=289$ Kelvin.

\section{B. Pressure of Engine:}

From gas Equation, PV = MRT

Where

$\mathrm{P}=$ Pressure of the engine,

$\mathrm{V}=$ Total volume of the engine,

$\mathrm{R}=$ Gas constant

Where,

$\mathrm{R}=\mathrm{Rx} / \mathrm{mw}$

$\mathrm{Rx}=8.3143$,

$\mathrm{Mw}$ is molecular weight $=114.228 \mathrm{~g} / \mathrm{cc}$

$\mathrm{Mw}=114228 \mathrm{~kg} / \mathrm{cc}$

So,

$$
\mathrm{R}=8.3143 / 114228=73
$$

$\mathrm{T}=289$ kelvin.

$\mathrm{M}=$ mass of the engine,

Where,

$$
\text { Mass }=\text { Density } \times \text { Volume }
$$

Density $=737.33 \mathrm{E}^{-9} \mathrm{~kg} / \mathrm{mm}^{3}$

Volume $=149.5 \mathrm{E}^{3} \mathrm{~mm}^{3}$

$$
\text { Mass }=737.33 \mathrm{E}^{-9} \times 148 \mathrm{E}^{3}=0.11 \mathrm{~kg}
$$

From the gas Equation,

$$
\mathrm{PV}=\mathrm{MRT} \text {, }
$$

Gas pressure, $\mathrm{P}=\mathrm{MRT} / \mathrm{V}$

$$
\mathrm{P}=(0.11 \times 72.786 \times 288.88) / 149 \mathrm{E}^{3}=15.5
$$


Pressure $=15.5 \mathrm{MPa}$ or $\mathrm{N} / \mathrm{mm}^{2}$

\section{DESIGN AND ANALYSIS OF CONNECTING ROD}

A connecting rod is a machine member which is subjected to alternating direct compressive and tensile forces. Since the compressive forces are much higher than the tensile force, therefore the cross-section of the connecting rod is designed as a strut and the Rankine formula is used. A connecting rod subjected to an axial load $\mathrm{W}$ may buckle with $\mathrm{x}$-axis as neutral axis in the plane of motion of the connecting rod, $\{$ or $\} \mathrm{y}$-axis is a neutral axis [10-13]. The connecting rod is considered like both ends hinged for buckling about $\mathrm{x}$-axis and both ends fixed for buckling about y-axis. A connecting rod should be equally strong in buckling about either axis.

According to Rankine formulae,

$\mathrm{W}_{\text {cr }}$ about $\mathrm{X}$ axis,

$[\sigma c \times A] 1+a[L \div K x x]^{2}=[\sigma c \times A] 1+a[l \div K x x]^{2}$

$[\therefore$ for both ends hinged $L=l]$

$\mathrm{W}_{\mathrm{cr}}$ about $\mathrm{Y}$ axis,

$1+a[L \div K y y]^{2}=[\sigma c \times A] 1+a[l \div 2 K y y]^{2}$

[ $\therefore$ for both ends fixed $L=l / 2$ ]

In order to have a connecting rod equally strong in buckling about both the axis, the buckling loads must be equal. i.e.

$=[\sigma c \times A] 1+a[l \div K x x]^{2}=[\sigma c \times A] 1+a[l \div 2 K y y]^{2}$ [Or]

$=[l \div K x x]^{2}=[l \div 2 K y y]^{2}$

$\mathrm{K}^{2} \mathrm{xx}=4 \mathrm{~K}^{2} \mathrm{yy}$ [Or]

$\mathrm{I} \mathrm{xx}=$ 4Iyy

$$
\left[\therefore I=A \times K^{2}\right]
$$

This shows that the connecting rod is four times strong in buckling about $y$-axis than about $\mathrm{x}$-axis. If I $\mathrm{xx}>4 \mathrm{Iyy}$, Then buckling will occur about $\mathrm{y}$-axis and if I xx < 4Iyy, then buckling will occur about $\mathrm{x}$-axis. In Actual practice I xx is kept slightly less than 4Iyy. It is usually taken between 3 and 3.5 and the Connecting rod is designed for buckling about $\mathrm{x}$ axis. The design will always be satisfactory for buckling about y-axis. [6-9] The most suitable section for the connecting rod is I-section with the proportions shown $\mathrm{mfg}$.

Area of the cross section $\quad=2[4 \mathrm{t} \times \mathrm{t}]+3 \mathrm{t} \times \mathrm{t}=11 \mathrm{t}^{2}$

Moment of inertia about $\mathrm{x}$-axis $\quad=2[4 \mathrm{t} \times \mathrm{t}]+3 \mathrm{t} \times \mathrm{t}=11 \mathrm{t}^{2}$

Moment of inertia about $\mathrm{x}$-axis I $\mathrm{xx}=$

$$
112[4 t\{5 t\} 3-3 t\{3 t\} 3]=41912[t 4]
$$

And moment of inertia about $y$-axis I YY

$$
\begin{aligned}
=2 \times 112 \times \mathrm{t} \times\{4 \mathrm{t}\} 3+112\{3 \mathrm{t}\} \mathrm{t}^{3} & =13112\left[\mathrm{t}^{4}\right] \mathrm{I} \times x / \mathrm{IYY} \\
& =[419 / 12] \times[12 / 131] \\
& =3.2 \mathrm{~mm}
\end{aligned}
$$

Since the value of IXx / IYY lies between 3 and $3.5 \mathrm{~m}$ therefore I-section chosen is quite satisfactory.

\section{A. Design Calculations for Existing Connecting Rod:}

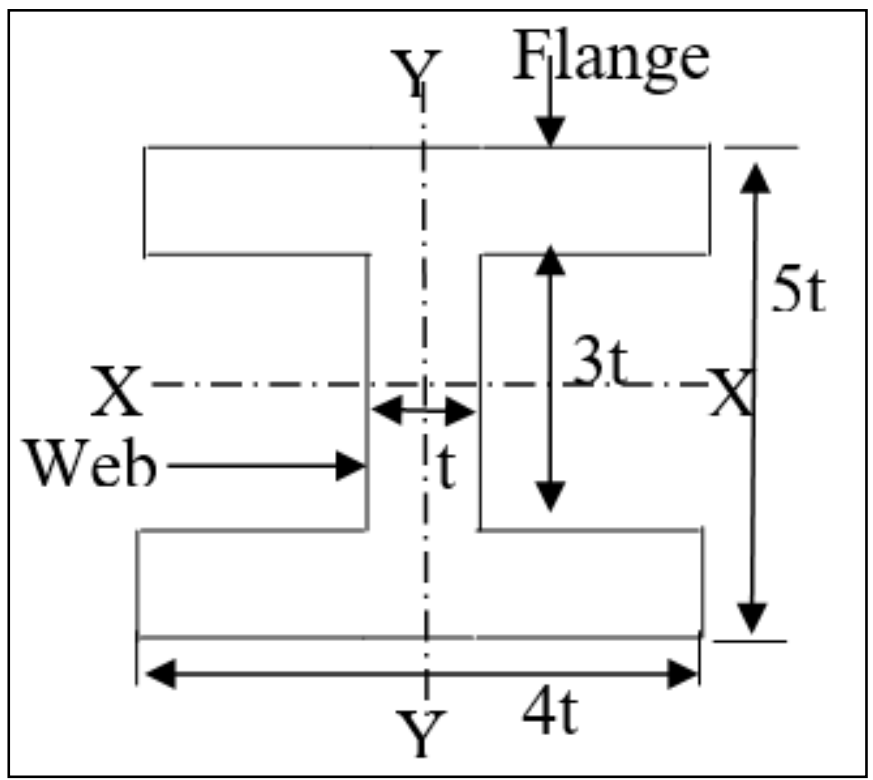

Fig. 3. I - Section of connecting rod

Thickness of flange $\&$ web of the section $=t$

Width of section B

$=4 \mathrm{t}$

The standard dimension of I Section.

Height of section $\mathrm{H} \quad=5 \mathrm{t}$

Area of section $A=2(4 t \times t)+3 t \times t \quad=11 t^{2}$

M.O.I of section about $\mathrm{x}$ axis:

I xx $=1 / 12\left[4 t\left\{5 t^{3}-3 t\{3 t\}^{3}\right]\right.$

$$
=419 / 12(\mathrm{t})^{4}
$$

MI of section about $y$ axis:

Iyy $=2 \times 1 / 12 \times t \times\{4 t\} 3+1 / 12\{3 t\} t^{3}$

Ixx $\div$ Iyy $=3.2 \mathrm{~mm}$

$$
=131 / 12\left[\mathrm{t}^{4}\right]
$$

Length of connecting rod $(\mathrm{L})=2$ times the stroke $\mathrm{L}=\mathbf{1 1 7 . 2} \mathbf{~ m m}$

Buckling load $\mathrm{WB}=$ maximum gas force $\times$ F.O.S

$\mathrm{WB}=(\sigma c \times A) \div\left(1+\mathrm{a}(\mathrm{L} / \mathrm{Kxx})^{2}\right.$

$$
=37663 \mathrm{~N}
$$

$\sigma c=$ compressive yield stress $=415 \mathrm{MPa}$

$\mathrm{K} \mathrm{xx}=\mathrm{I} \mathrm{xx} \div \mathrm{A}$

$$
\begin{aligned}
& \mathrm{Kxx}=1.78 \mathrm{t} \\
& \mathrm{a}=\sigma c \div \pi 2 E \\
& \mathrm{a}=0.0002
\end{aligned}
$$

Where,

By substituting $\sigma c, \mathrm{~A}, \mathrm{a}, \mathrm{L}, \mathrm{Kxx}$ on WB then

$$
\begin{aligned}
& =4565 \mathrm{t}^{4}-37663 \mathrm{t}^{2}-81639.46=0 \\
& \mathrm{t}^{2}=10.03 \\
& \mathrm{t}=3.167 \mathrm{~mm} \\
& \mathbf{t}=\mathbf{3 . 2} \mathbf{m m}
\end{aligned}
$$

Width of section $B=4 t$

$$
\begin{gathered}
B=4 \times 3.2 \\
B=\mathbf{1 2 . 8 m m}
\end{gathered}
$$




\section{International Journal of Engineering Applied Sciences and Technology, 2020 \\ Vol. 4, Issue 12, ISSN No. 2455-2143, Pages 562-569 \\ Published Online April 2020 in IJEAST (http://www.ijeast.com)}

Height of section $\mathrm{H}=5 \mathrm{t}$

$$
\begin{aligned}
& =5 \times 3.2 \\
& =16 \mathrm{~mm}
\end{aligned}
$$

Area $\mathrm{A}=11 \mathrm{t}^{2}$

$$
\begin{aligned}
& \text { Area } A=11 \times 3.2 \times 3.2 \\
& \text { Area }=\mathbf{1 1 2 . 6} \mathbf{~ m m}^{2}
\end{aligned}
$$

Height at the big end (crank end) $=\mathrm{H}_{2}$

$$
\begin{aligned}
& =1.1 \mathrm{H} \text { to } 1.25 \mathrm{H} \\
& =1.1 \times 16 \\
& \mathbf{H}_{\mathbf{2}}=\mathbf{1 7 . 6 m m}
\end{aligned}
$$

Height at the small end (piston end) $=0.9 \mathrm{H}$ to $0.75 \mathrm{H}$

$$
\begin{aligned}
& =0.9 \times 16 \\
& \mathbf{H}_{\mathbf{1}}=\mathbf{1 2 \mathbf { m m }}
\end{aligned}
$$

Stroke length $(\mathrm{l})=117.2 \mathrm{~mm}$

Diameter of piston (D) $=57 \mathrm{~mm}$

Pressure $=15.5 \mathrm{~N} / \mathrm{mm} 2$

Radius of $\operatorname{crank}(\mathrm{r})=$ stroke length $/ 2$

$$
\mathrm{r}=58.6 / 2
$$$$
\mathbf{r}=29.3 \mathrm{~mm}
$$

Maximum force on the piston due to pressure

$\mathrm{FL}=\pi \div 4 \times \mathrm{D}^{2} \times \mathrm{p}$

$\mathrm{FL}=\pi / 4 \times(57)^{2} \times 15.469$

$$
\text { FL }=39473.16 N
$$

Maximum angular speed

$\mathrm{Wmax}=[2 \pi \mathrm{Nmax}] \div 60$

$$
\begin{aligned}
& =[2 \pi \times 8500] \div 60 \mathrm{~A} \\
& =\pi r^{2}
\end{aligned}
$$

$\mathrm{W}_{\text {max }}=768 \mathrm{rad} / \mathrm{sec}$

Ratio of the length of connecting rod to the radius of crank

$$
\mathrm{N}=1 \div \mathrm{r}=112 /(29.3)
$$$$
=3.8
$$

Maximum Inertia force of reciprocating parts

$$
\begin{aligned}
& \mathrm{F}_{\mathrm{im}}=\mathrm{M}_{\mathrm{r}}(\mathrm{Wmax}) 2 \mathrm{r}(\cos \theta+\operatorname{COS} 2 \theta \div \mathrm{n}) \\
& \mathrm{F}_{\text {im }}=\operatorname{Mr}(\mathrm{Wmax}) 2 \mathrm{r}(1+1 \mathrm{n}) \\
& \mathrm{F}_{\mathrm{im}}=0.11 \times(768) 2 \times(0.0293) \times(1+(1 / 3.8)) \\
& \mathrm{F}_{\mathrm{im}}=\mathbf{2 3 7 6 . 2 6 N}
\end{aligned}
$$

Inner diameter of the small end (d1)

$$
\begin{aligned}
& D_{1}=F_{g} \div\left(p_{1 \times} t_{1}\right) \\
& D_{1}=6277.167 \div(12.5 \times 1.5 \mathrm{~d} 1) \\
& \text { D1 }=\mathbf{1 7 . 9 4 m m}
\end{aligned}
$$

Where,

Design bearing pressure for small end $\mathrm{pb} 1=$

$$
\begin{aligned}
12.5 & \text { to } 15.4 \mathrm{~N} / \mathrm{mm}^{2} \\
= & (1.5 \text { to } 2) \mathrm{d} 1 \\
= & \mathrm{d} 1+2 \mathrm{tb}+2 \mathrm{tm} \\
= & 17.94+[2 \times 2]+[2 \times 5] \\
& \mathbf{D}_{\mathbf{2}}=\mathbf{3 1 . 9 4 m m}
\end{aligned}
$$

\begin{tabular}{|c|c|c|}
\hline $\begin{array}{l}\text { S. } \\
\text { NO }\end{array}$ & Parameters & $\begin{array}{c}\text { Dimensions } \\
(\mathbf{m m})\end{array}$ \\
\hline 1 & Thickness of the connecting $\operatorname{rod}(\mathrm{t})$ & 3.2 \\
\hline 2 & Width of the section $(B=4 t)$ & 13 \\
\hline 3 & Height of the section $(\mathrm{H}=5 \mathrm{t})$ & 16 \\
\hline 4 & Height of the connecting rod big end $\left(\mathrm{H}_{1}\right)$ & 18 \\
\hline 5 & $\begin{array}{l}\text { Height of the connecting rod small } \\
\text { end }\left(\mathrm{H}_{2}\right)\end{array}$ & 15 \\
\hline 6 & Inner diameter of the small end( $\left.\mathrm{D}_{\mathrm{SI}}\right)$ & 33 \\
\hline 7 & Outer diameter of the big end( $\left.\mathrm{D}_{\mathrm{SO}}\right)$ & 19 \\
\hline 8 & Inner diameter of the big end( $\left.\mathrm{D}_{\mathrm{BI}}\right)$ & 47 \\
\hline 9 & Outer diameter of the big end $\left(\mathrm{D}_{\mathrm{BO}}\right)$ & 24 \\
\hline
\end{tabular}

Where,

$\begin{array}{ll}\text { Thickness of the bush }\left(\mathrm{t}_{\mathrm{b}}\right) & =2 \text { to } 5 \mathrm{~mm} \\ \text { Marginal thickness }\left(\mathrm{t}_{\mathrm{m}}\right) & =5 \text { to } 15 \mathrm{~mm}\end{array}$

Inner diameter of the big end $\mathrm{d}_{\mathrm{BI}}=\mathrm{Fg} \div(\mathrm{Pb} 2 \times 12)$

$$
\mathrm{d}_{\mathrm{BI}}=6277.167 \quad 10.8 \times 1.0 \mathrm{~d} 1
$$

\section{$\mathrm{d}_{\mathrm{BI}}=\mathbf{2 3 . 8 8 \mathrm { mm }}$}

Where,

Design bearing pressure for big end $(\mathrm{pb} 2)=$

10.8 to $12.6 \mathrm{~N} / \mathrm{mm}^{2}$

Length of the crank pin (12) $=(1.0$ to 1.25$) \mathrm{d} 2$

Root diameter of the bolt $=$

$$
\begin{gathered}
((2 \mathrm{Fim}) \div(\pi \mathrm{xSt}))^{1 / 2}=(2 \times 6277.167 \pi \times 56.667)^{1 / 2} \\
\mathbf{R}_{\mathbf{d}}=\mathbf{4} \mathbf{m m}
\end{gathered}
$$

Outer diameter of the big end $=\mathrm{d} 2+2 \mathrm{tb}+2 \mathrm{db}+2 \mathrm{tm}$

$$
=23.88+2 \times 2+2 \times 4+2 \times 5
$$

Where,

Thickness of the bush [tb]

Marginal thickness [tm]

$=47.72 \mathrm{~mm}$

Nominal diameter of bolt $\left[\mathrm{d}_{\mathrm{b}}\right]$

$=2$ to $5 \mathrm{~mm}$

Diameter of the bolt

$=5$ to $15 \mathrm{~mm}$

$=1.2 \times$ root

$=1.2 \times 4$

$D_{b}=4.8 \mathrm{~mm}$

\section{B. Specification of Connecting Rod:}

Table -1 Dimensions of connecting rod

\section{Modeling of the Connecting Rod using CATIA V15:}

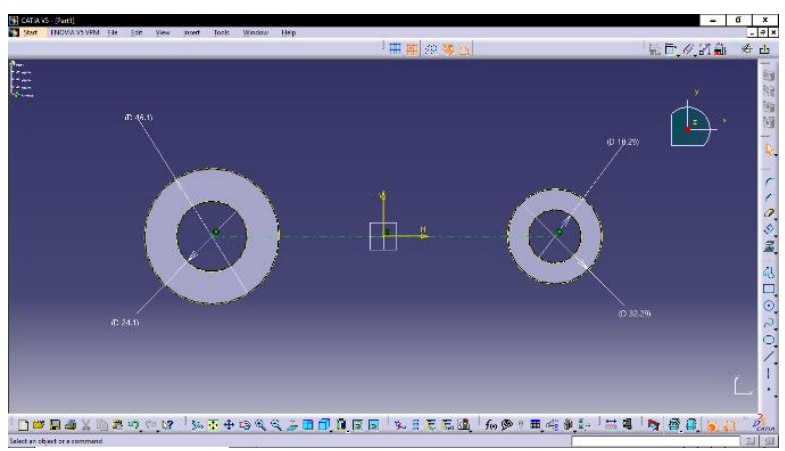

Fig. 4. Making of Stempad 
International Journal of Engineering Applied Sciences and Technology, 2020

Vol. 4, Issue 12, ISSN No. 2455-2143, Pages 562-569

Published Online April 2020 in IJEAST (http://www.ijeast.com)

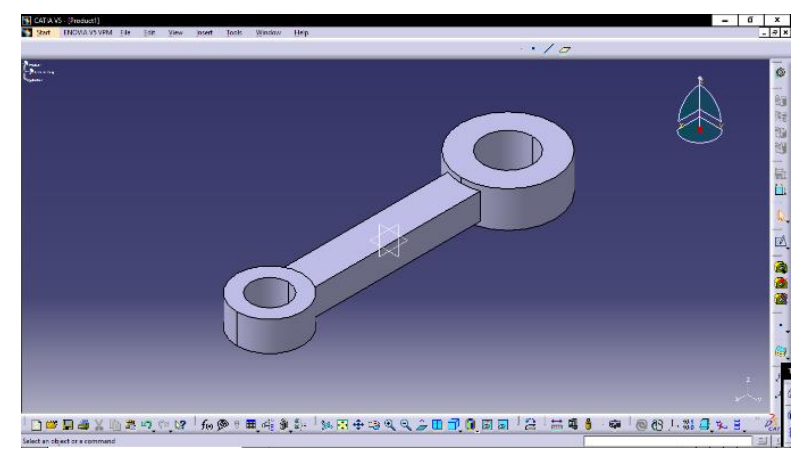

Fig. 5. Stem pad Sketch

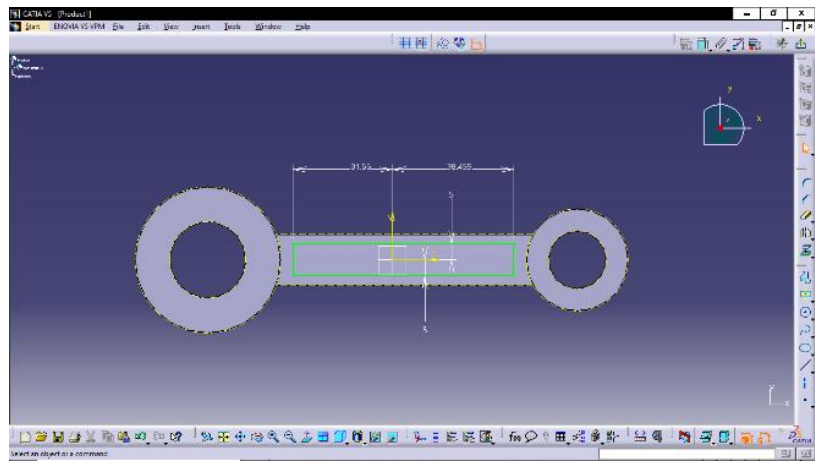

Fig. 6. Weight Reduction

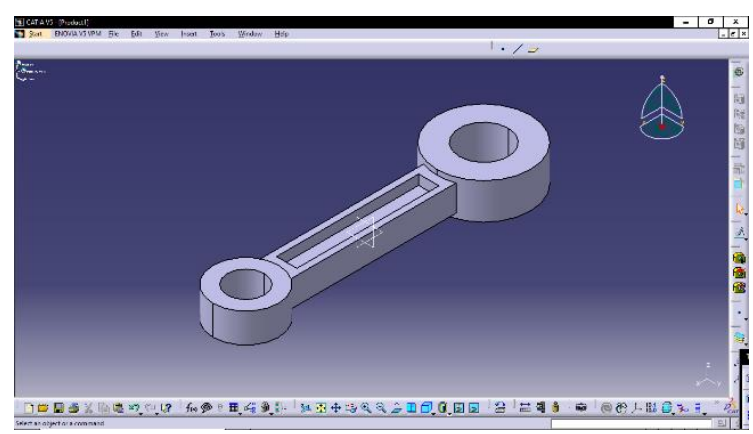

Fig. 7. Pocket Sketch

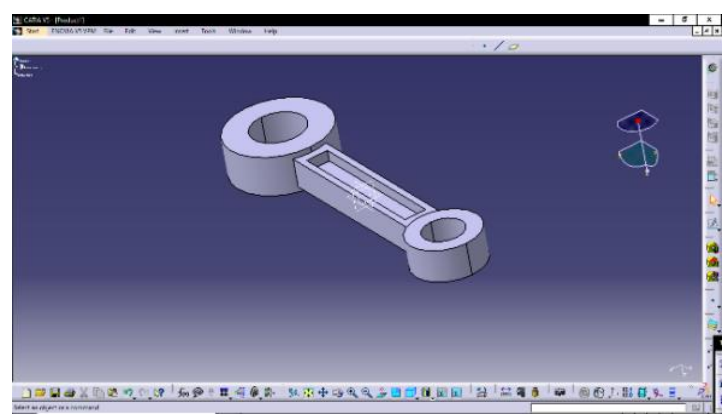

Fig. 8. Mirror of Pocket

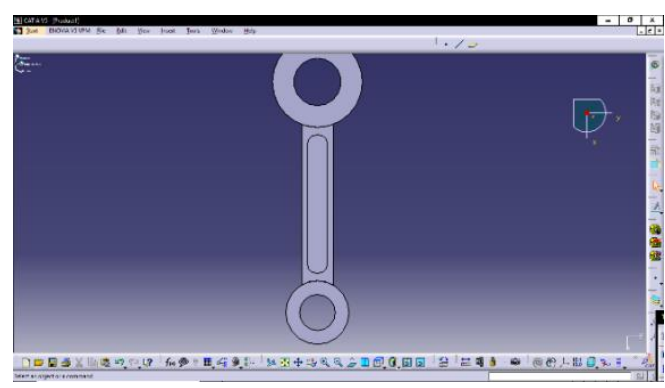

Fig. 9. Edge Fillet

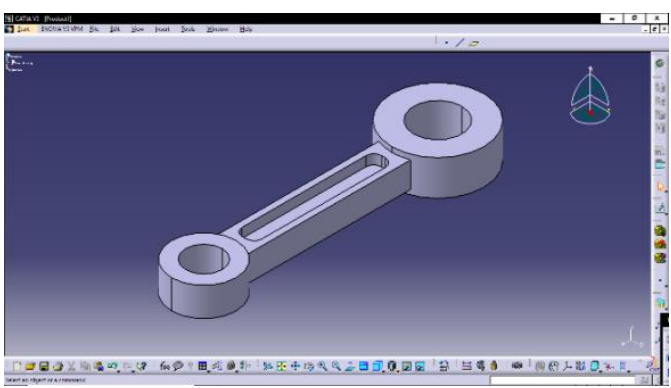

Fig. 10. Connecting Rod

D. Analysis of the Connecting Rod using ANSYS V14.2

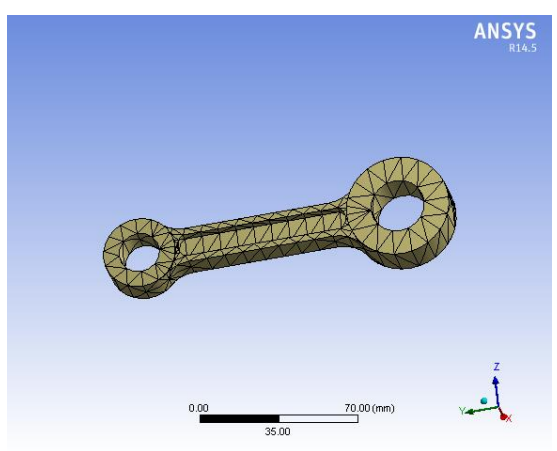

Fig. 11. Meshing

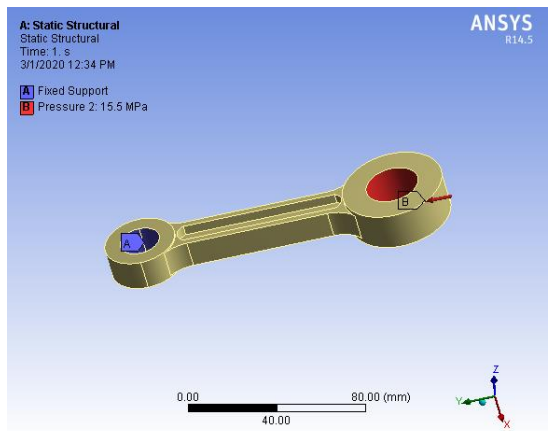

Fig. 12. Load Condition 
International Journal of Engineering Applied Sciences and Technology, 2020

Vol. 4, Issue 12, ISSN No. 2455-2143, Pages 562-569

Published Online April 2020 in IJEAST (http://www.ijeast.com)

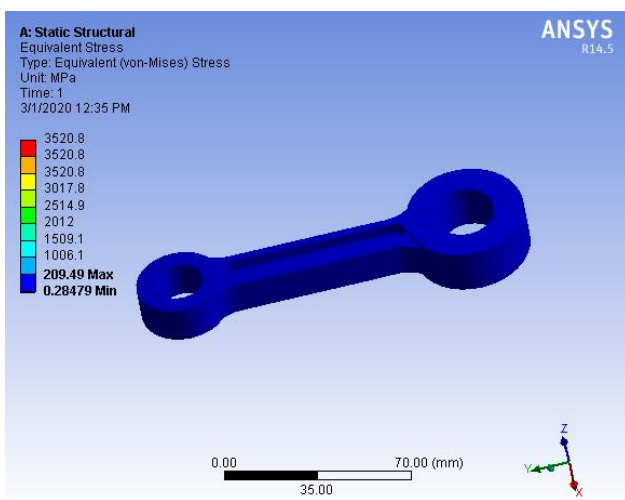

Fig. 13. Equivalent Stress

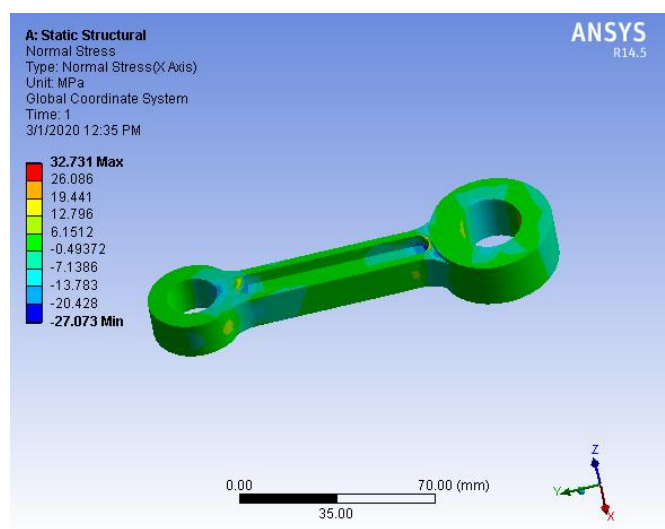

Fig. 14. Normal Stress(X axis)

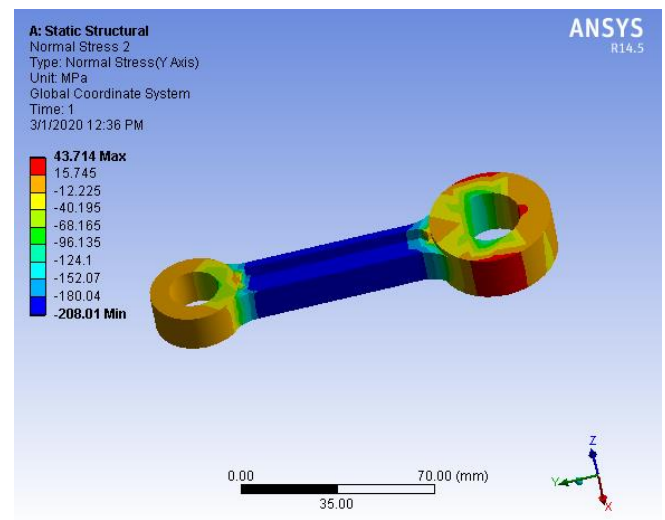

Fig. 15. Normal Stress (Y axis)

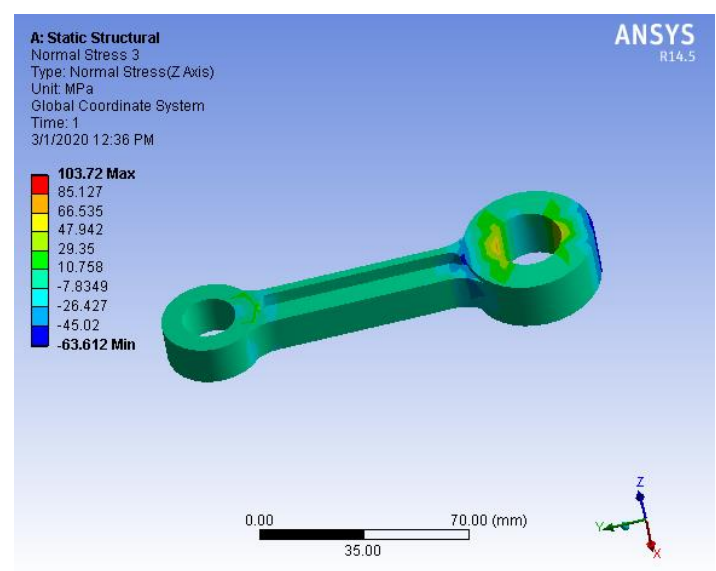

Fig. 16. Normal Stress ( $\mathrm{Z}$ axis)

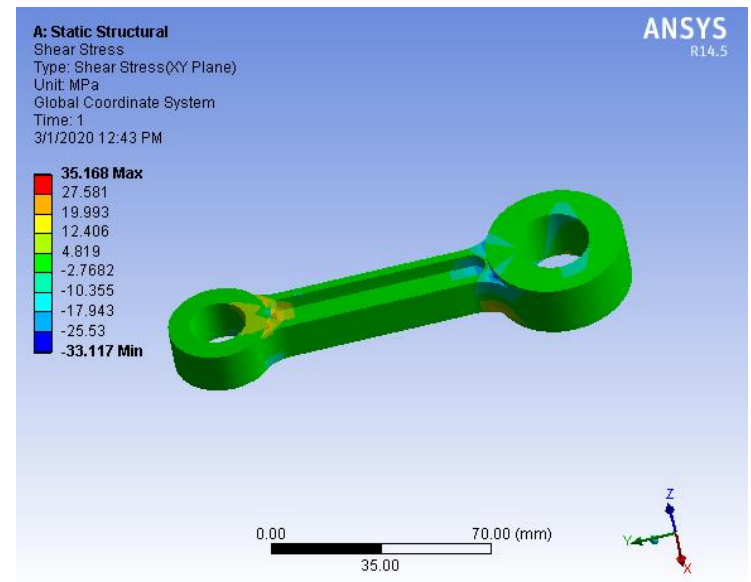

Fig. 17. Shear Stress (XY axis)

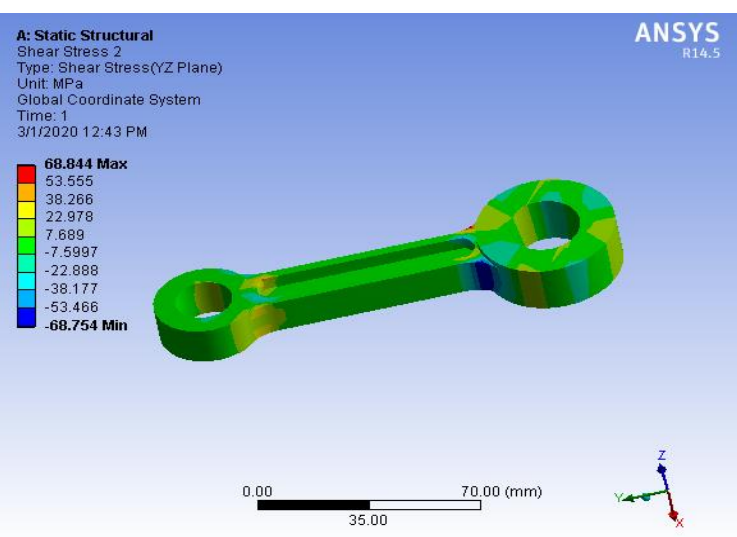

Fig. 18. Shear Stress (YZ axis) 
International Journal of Engineering Applied Sciences and Technology, 2020

Vol. 4, Issue 12, ISSN No. 2455-2143, Pages 562-569

Published Online April 2020 in IJEAST (http://www.ijeast.com)

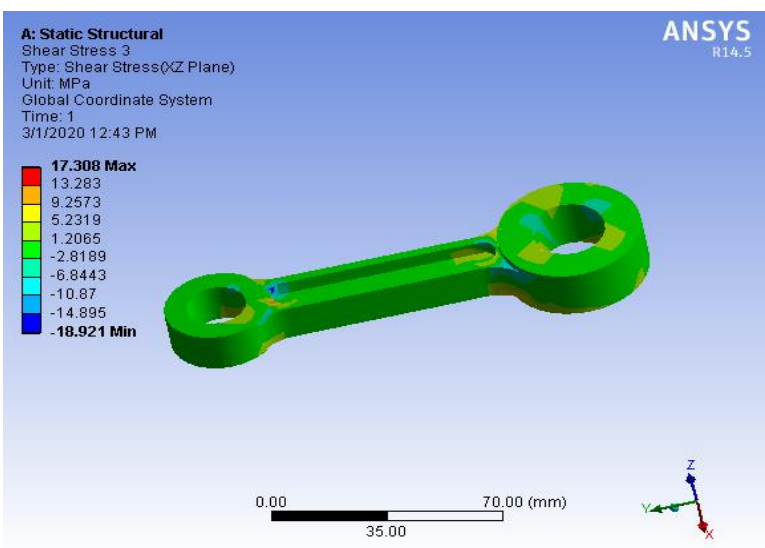

Fig. 19. Shear Stress ( $\mathrm{ZX}$ axis)

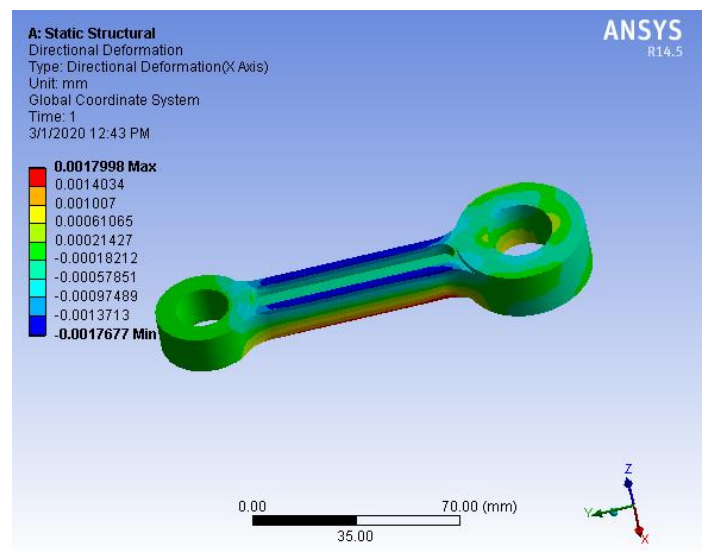

Fig. 20. Directional Deformations ( $\mathrm{X}$ axis)

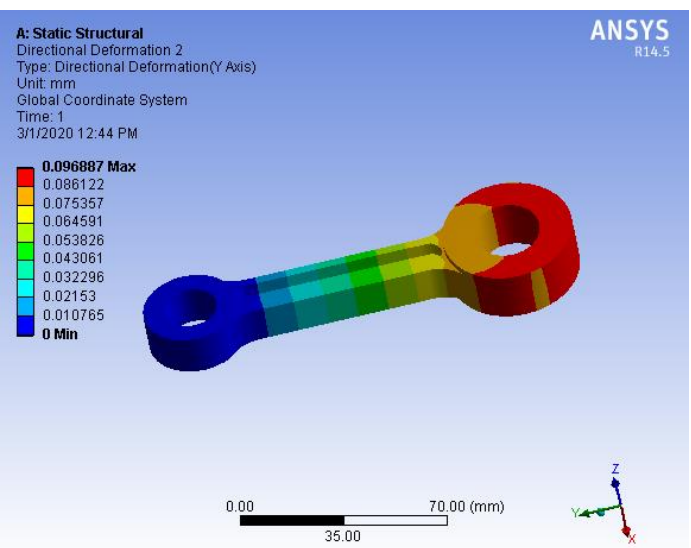

Fig. 21. Directional Deformations (Y axis)

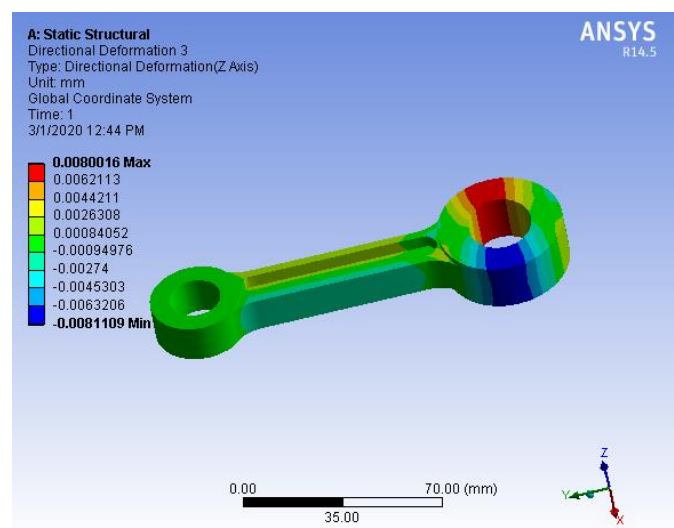

Fig. 22. Directional Deformations ( $\mathrm{Z}$ axis)

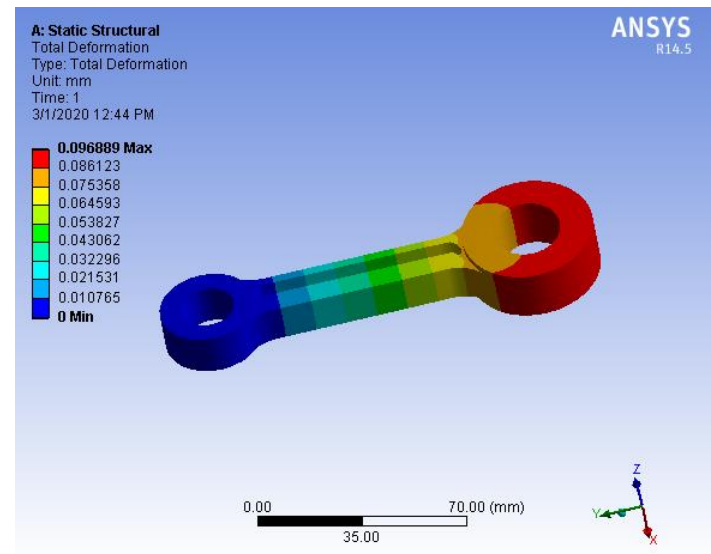

Fig. 23. Total Deformations

IV. RESULT AND DISCUSSION

A. Stresses and Deformation of the Manganese Alloy Steel:

Table 2- Stresses and Deformation

\begin{tabular}{|c|l|c|c|}
\hline S.no & \multicolumn{1}{|c|}{ Type of Stresses } & Max(MPa) & Min(MPa) \\
\hline 1 & Equivalent stress & 210.1 & 0.26943 \\
\hline 2 & $\begin{array}{l}\text { Normal stress } \\
\text { (X axis) }\end{array}$ & 31.996 & -26.996 \\
\hline 3 & $\begin{array}{l}\text { Normal stress } \\
\text { (Y axis) }\end{array}$ & 43.561 & -208.83 \\
\hline 4 & $\begin{array}{l}\text { Normal stress } \\
(\text { Z axis })\end{array}$ & 102.96 & -65.578 \\
\hline 5 & $\begin{array}{l}\text { Shear stress } \\
\text { (XY axis) }\end{array}$ & 35.168 & -33.117 \\
\hline
\end{tabular}


International Journal of Engineering Applied Sciences and Technology, 2020

Vol. 4, Issue 12, ISSN No. 2455-2143, Pages 562-569

Published Online April 2020 in IJEAST (http://www.ijeast.com)

\begin{tabular}{|c|l|c|c|}
\hline 6 & $\begin{array}{l}\text { Shear stress } \\
\text { (YZ axis) }\end{array}$ & 68.844 & -68.754 \\
\hline 7 & $\begin{array}{l}\text { Shear stress } \\
\text { (XZ axis) }\end{array}$ & 17.308 & 18.921 \\
\hline S.no & $\begin{array}{c}\text { Directional } \\
\text { Deformations }\end{array}$ & Max(mm) & Min(mm) \\
\hline 1 & (X axis) & 0.0017998 & -0.001767 \\
\hline 2 & (Y axis) & 0.09887 & 0 \\
\hline 3 & (z axis) & 0.0080016 & -0.00811 \\
\hline
\end{tabular}

- Also, number of cycles of Manganese alloy steel is more than the existing Forged steel connecting rod.

- When compared both the materials, Manganese steel is cheaper than the existing forged steel material.

\section{REFERENCE}

[1] N. Chen, L. Han, W. Zhang and X. Hao (2006) ,Enhancing Mechanical Properties and Avoiding Cracks by Simulation of Quenching Connecting Rod". Material Letters, 61: 3021-3024.

[2] El - Sayed, M.E.M. and E.H. Lund (1990), "Structural optimization with fatigue life constraints," Engineering Fracture Mechanics, 37(6): 1149-1156.

[3] Jahed Motlagh, H.M. Nouban and M.H. Ashraghi(2003), "Finite Element Analysis of connecting rod using ANSYS". University of Tehran Publication, PP: 990.

Table 3- Mechanical Properties

\begin{tabular}{|c|l|c|c|}
\hline S.no & Mechanical Properties & $\begin{array}{c}\text { Forged } \\
\text { Steel }\end{array}$ & $\begin{array}{c}\text { Manganese } \\
\text { alloy steel }\end{array}$ \\
\hline 1. & Density( g/cc) & 7.7 & 7.1 \\
\hline 2. & $\begin{array}{l}\text { Average hardness } \\
\text { (HRB) }\end{array}$ & 101 & 94 \\
\hline 3. & $\begin{array}{l}\text { Modulus of } \\
\text { Elasticity,(Gpa) }\end{array}$ & 221 & 208 \\
\hline 4. & Yield Strength (Mpa) & 625 & 614 \\
\hline 5. & Ultimate Strength (Mpa) & 625 & 612 \\
\hline 6. & Poison ratio & 0.29 & 0.24 \\
\hline
\end{tabular}

\section{CONCLUSION}

Static analysis of the connecting rod has been made successfully by using ANSYS v14.2 workbench. From the static analysis, many discussions have been made. The obtained results are well in agreement with the similar to existing materials result. By checking and comparing the results of forged steel and Manganese alloy steel, the conclusions are given below.

Considering various parameters,

- Equivalent stresses for both the materials are same.

- The Manganese alloy steel, factor of safety and stiffness is increased compared to forged steel.

- The weight of Manganese alloy steel is less than Forged steel.

- From the Fatigue analysis, life time of the connecting rod can be increased.

[4] M Khanali (2006),, "Stress analysis of frontal axle of JD 955 combines". M.Sc. Thesis. Thran University, 124.

[5] A. Afzal, and A. Fatemi (2004), "A comparative study of fatigue behavior and life predictions of forged steel and PM connecting rods". SAE Technical Paper.

[6] B. Repgen (1998), "Optimized Connecting Rods to Enable Higher Engine Performance and Cost Reduction," SAE Technical Paper Series, Paper No. 980882.

[7] Saswat satpathy, Subhransu K Panda and Pradeep K Mishra (2019)" Static and fatigue damage analysis of a connecting rod", Research scholar, CAPGS,BPVT, Rourkela.

[8] Adila Afzal and Ali Fatemi (2003), "A Comparative Study of Fatigue Behavior and Life Predictions of Forged Steel and PM Connecting Rods", SAE International.

[9] G Augugliaro and M E Biancolini, "Optimisation of Fatigue Performance of a Titanium Connecting Rod", ISPESL, Italy, 2010.

[10] P G Charkha and S B Jaju (2009), "Analysis \& Optimization of Connecting Rod", 2nd International Conference on Emerging Trends in Engineering and Technology, ICETET-09.

[11] R Hippoliti (1993), "FEM Method for Design and Optimization of Connecting Rods for Small Two-Stroke Engines", Small Engine Technology Conference, pp. 217231.

[12] R.A Savanoor, Abhishek patil, Rakesh patil and Amit rodagi "Finite element analysis of IC engine connecting rod by ansys"- Int J Mech.Eng.

[13] V Sarihan and J Song (1990), "Optimization of the Wrist Pin End of an Automobile Engine Connecting Rod with an Interference Fit", Journal of Mechanical Design, Transactions of the ASME, Vol. 112, pp. 406-412. 